\title{
Efficacy of Carbofuran in Controlling Root-Knot Nematode (Meloidogyne javanica Whitehead, 1949) on Cultivars of Bambara Groundnut (Vigna subterranea (L.) Verdc.) in Yola, Nigeria
}

\author{
M. Y. Jada, D. T. Gungula, and I. Jacob \\ Department of Crop Production and Horticulture, Federal University of Technology, Yola, Nigeria \\ Correspondence should be addressed to D. T. Gungula, dgungula@yahoo.com
}

Received 28 July 2010; Revised 14 February 2011; Accepted 10 April 2011

Academic Editor: Kassim Al-Khatib

Copyright ( $) 2011$ M. Y. Jada et al. This is an open access article distributed under the Creative Commons Attribution License, which permits unrestricted use, distribution, and reproduction in any medium, provided the original work is properly cited.

\begin{abstract}
Bambara groundnut (Vigna subterrenea L. Verdc.) is an important crop produced in Adamawa State of Nigeria. However, the production of the crop is seriously threatened by root-knot nematodes (RKNs; Meloidogyne spp.). Since cultural methods have not been very effective in controlling RKN, carbofuran was evaluated to determine its efficacy in controlling M. javanica in Yola during 2002 and 2003. Three bambara groundnut cultivars (Kwachanjiwa, Kwaheuma, and Kwatolotolo) were evaluated using three application timings (at planting, 3 and 6 weeks after planting, and none). Results indicated that applying carbofuran at planting provided the greatest reduction in M. javanica population levels, which lead to increased yields in bambara groundnuts compared to the other two application timings. Furthermore, both Kwachanjiwa and Kwatolotolo provided similar high yields compared to Kwaheuma, which was most likely related to the M. javanica tolerance in these cultivars.
\end{abstract}

\section{Introduction}

Bambara groundnut (Vigna subterranea L. Verdc.) is a tropical leguminous crop. According to Rowland [1], the crop contains $4.6 \%$ oil, $16-21 \%$ protein, and $50-61.3 \%$ carbohydrate. It is cultivated throughout northern Nigeria and many African and Asian countries [2]. Unlike other legumes particularly cowpea, bambara groundnut is known to have less insect pests, but it is highly susceptible to rootknot nematode [1]. Bambara groundnut yields are generally low in Africa, averaging between 650 and $850 \mathrm{~kg} / \mathrm{ha}$ [2]. One of the major causes of the low yield of bambara groundnut apart from genetic potential is the effect of diseases and pests like nematodes. Therefore, to increase the yield of the crop, pest and disease management is a critical criterion. Farmers in this locality have used several cultural methods to manage pests but have recorded little or no success. Several of them have thus opted for other crops thus reducing the cultivation of bambara groundnut. This has negative effects on the production of the crop.

Carbofuran has been reported to control nematodes [3]. Low galling index in soybean plants treated with carbofuran by both soil drench and soil drench + foliar application has been reported [4]. Furthermore it has been reported that the application of $700 \mathrm{ppm}$ on soyabean plants as soil drench reduced the number of $M$. incognita eggs that hatched into juveniles [4]. In an experiment where carbofuran 3G was applied at the rates of $0,100,200$, and $300 \mathrm{~kg} / \mathrm{ha}$ to three hybrid yam varieties in southwestern Nigeria [5] there was an increase in the yield of the three hybrid yam varieties, which was significantly higher than in the control. Optimum yields were obtained from the application of $100 \mathrm{~kg} / \mathrm{ha}$ applied at 3 months after planting (MAP). Carbofuran influenced severity of nematode infection on tubers. It was observed that carbofuran application significantly reduced incidence and severity of nematode infestation on tubers by reducing the gall index and reproduction factor, preventing or limiting hatching of eggs and the movement of larvae into roots. Elsewhere, prophylactic effects of Furadan increased plant height and vegetative growth of plants $[6$, 7]. Carbofuran application has been observed to produce normal plant height in crops while nematode infestation reduces plant height [8]. Similarly, soil application of carbofuran at a rate of $2 \mathrm{~kg}$ a.i./ha reduced soil populations of 
Scutellonema bradys to very low levels with remarkable yield increases recorded.

The choice of carbofuran is because it is nonpersistence and rapidly metabolizable and does not pass along the food chain. Like other carbamates it is metabolized rapidly in animals into less toxic and finally nontoxic metabolites [5].

There is the need to identify the right quantity of carbofuran which, if applied, will not hinder nodulation in soyabean and at the same time will effectively control nematodes. This may also require the knowledge of the right time of application of the nematicide. However, the time of application of the nematicide for effective control of nematodes has not been reported in the study area. Therefore, this work was carried out to determine the best time for the application of carbofuran to effectively control M. javanica in bambara groundnut. This will lead to improved performance of bambara groundnut and lead to more farmers producing the crop.

\section{Materials and Method}

The research was conducted for two years during 2002 and 2003 growing seasons at the Teaching and Research Farm of the Department of Crop Production and Horticulture, Federal University of Technology, Yola.

The land was ploughed and leveled, and the experiment was laid out in a split plot design with bambara groundnut cultivars as main plot treatment while the time of carbofuran application was the subplot treatment. Granules ("G") of Furadan (carbofuran) are low-strength formulations meant to be applied without dilution. They are especially well suited for soil applications. Furadan $3 \mathrm{G}$ is a granular formulation that contains 3\% pure Furadan. Although carbofuran is banned in many countries, it still remains one of the most effective control measures against root-knot nematode. Moreover, the quantity required per hectare is small. Therefore, it can easily be afforded by poor resource farmers. The subplots were $3 \mathrm{~m}^{2}$ with $1 \mathrm{~m}$ pathway between main plots and also between the 3 replicates. The cultivars used were Kwachanjiwa, Kwaheuma, and Kwatolotolo. Carbofuran was applied at the rate of $40 \mathrm{~g} / \mathrm{plot}(4 \mathrm{~kg} / \mathrm{ha})$ of the granular formulation at planting, 3 and 6 WAS. A control was maintained where no chemical was applied. The field was planted on the $23 \mathrm{rd}$ of July, 2002 at $50 \mathrm{~cm} \times 10 \mathrm{~cm}$ spacing.

2.1. Description of Seeds Planted. Kwachanjiwa has smooth shiny, white creamy seed coat with grey eye. Kwaheuma has smooth shiny, dull white seed coat with black stripes pigmentation around the eye, and Kwatolotolo has smooth shiny brown creamy seed coat with brown stripes having white coloured eye. The seeds were obtained from the Department of Crop Production and Horticulture, Federal University of Technology, Yola.

2.2. Agronomic Practices. The soil is a sandy loam soil, therefore, compound fertilizer (NPK 15:15:15) was applied at the rate of $150 \mathrm{~kg} / \mathrm{ha}$ at the time of land preparation. The experiment was kept weed-free by weeding with hand hoe three times.

\subsection{Data Collection}

2.3.1. Nematode Extraction from Soil. Soil samples were taken from each plot to the depth of $15 \mathrm{~cm}$ using ordinary hoe, at five different points in a zig-zag form and then bulked to form a composite sample per plot. Each composite soil sample was placed in a polythene bag and properly labeled for identification. The soil samples were taken to the laboratory and kept at room temperature $\left(28-32^{\circ} \mathrm{C}\right)$. The nematodes were extracted from $250 \mathrm{~cm}^{3}$ of soil using improved Baermann's tray method as described by Barker [9]. The nematodes were counted under the microscope (x100) in a duncaster counting dish. The soil sampling and extraction were done at planting and at 14 weeks after sowing (WAS) when the plants were matured.

\subsubsection{Root Gall Count and Extraction of Nematodes from the} Roots. At 8 WAS, five plants were uprooted from each plot at random. The root galls on the roots of each plant were counted and a mean value per plot computed. These means were then classified into galling index on a scale of $0-5$ as described by Barker [9]. Similarly, from the same plants, number of nodules was counted and the means computed. The roots were cut into $1 \mathrm{~cm}$ long pieces bulked and mixed thoroughly, before $10 \mathrm{~g}$ was weighed from each sample and nematodes extracted using Baermann's tray method as described by Barker [9].

\subsubsection{Flower Count, Plant Height, and Yield Measurement.} The number of flowers per plant for each plot was counted when the plants were 8 weeks old. At 10 WAS, height of 5 plants was measured at random in each plot using metre rule, and the average was recorded for the plot. The plants were harvested when they were fully matured and dried before depoding. The seeds were also sun-dried for three days to determine seed yield which was then expressed in $\mathrm{kg} / \mathrm{ha}$.

In 2003 growing season the same experiment was repeated, and all the parameters were taken as described for the 2002 cropping season.

\section{Results}

3.1. Effects of Carbofuran Application on the Population of Nematodes. There were significant differences $(P=.05)$ observed among the time of carbofuran application in $\mathrm{J}_{2}$ count $/ 250 \mathrm{~cm}^{3}$ soil at planting and at maturity and the $\mathrm{J}_{2}$ count $/ 10 \mathrm{~g}$ of roots at 8 WAS (Table 1 ). In 2002, the lowest $\mathrm{J}_{2}$ count of 877 in $250 \mathrm{~cm}^{-3}$ of soil was obtained from plots that received carbofuran application at 3 WAS (Table 1). Similarly, in 2003, the $\mathrm{J}_{2}$ count from plots that had carbofuran application at 3 WAS (967) was similar to that from the plots that received carbofuran application at 6 WAS (961) which was the lowest. The highest $J_{2}$ count at planting in both seasons was from the control treatment where there was no carbofuran application. Similarly, the highest $J_{2}$ count per $10 \mathrm{~g}$ of roots in both years was recorded from the control plots that received no carbofuran application while the lowest values were recorded from plots that received carbofuran application at planting. Even though carbofuran 
TABLE 1: Effects of carbofuran on the characteristics of M. javanica on bambara groundnut taken in 2002 and 2003 cropping seasons.

\begin{tabular}{|c|c|c|c|c|c|c|}
\hline \multirow{2}{*}{$\begin{array}{l}\text { Treatment } \\
\text { Application time }\end{array}$} & \multicolumn{2}{|c|}{$\mathrm{J}_{2}$ count $/ 250 \mathrm{~cm}^{3}$ soil at $8 \mathrm{WAS}$} & \multicolumn{2}{|c|}{$\mathrm{J}_{2} / 10 \mathrm{~g}$ of roots } & \multicolumn{2}{|c|}{$\mathrm{J}_{2} / 250 \mathrm{~cm}^{3}$ soil at maturity } \\
\hline & 2002 & 2003 & 2002 & 2003 & 2002 & 2003 \\
\hline Control & 1107.2 & 1028.40 & 31.33 & 34.67 & 1853.6 & 2208.20 \\
\hline At planting & 956.0 & 1144.90 & 7.00 & 3.89 & 248.9 & 158.10 \\
\hline 3WAS & 877.4 & 967.20 & 15.6 & 17.33 & 808.9 & 713.00 \\
\hline 6WAS & 1017.7 & 961.20 & 21.67 & 18.79 & 1097.1 & 1093.00 \\
\hline S.E. & 165.87 & 184.36 & 7.64 & 2.84 & 190.79 & 195.29 \\
\hline Prob. Of F & 0.001 & 0.001 & 0.05 & 0.01 & 0.01 & 0.01 \\
\hline \multicolumn{7}{|l|}{ Cultivars } \\
\hline Kwachanjiwa & 1021.1 & 1122.30 & 10.83 & 11.00 & 742.9 & 850.70 \\
\hline Kwaheuma & 979.9 & 887.60 & 14.00 & 15.83 & 1060.5 & 1024.70 \\
\hline Kwatolotolo & 967.8 & 1022.00 & 31.83 & 29.17 & 1202.4 & 1253.90 \\
\hline Prob. of F & ns & ns & 0.01 & 0.01 & ns & ns \\
\hline S.E. & 191.75 & 213.13 & 8.83 & 3.28 & 220.57 & 225.71 \\
\hline $\mathrm{TP} \times$ Cultivar & ns & ns & ns & $* *$ & ns & ns \\
\hline
\end{tabular}

${ }^{*}$ : significantly different at $P=.05,{ }^{* *}$ : significantly different at $P=.01$, ns: nonsignificantly different at $P=.05$, WAS: weeks after sowing.

could not completely control the M. javanica, its application at planting greatly reduced the nematode traits measured. A similar trend was observed when the data was pulled over the two seasons (Table 2).

The means squares from the pooled data over the two growing seasons show that there were no significant differences $(P=.05)$ between seasons for $\mathrm{J}_{2}$ count in $250 \mathrm{~cm}^{-3}$ of soil at planting and maturity and $\mathrm{J}_{2}$ count per $10 \mathrm{~g}$ of roots (Table 2 ).

There were significant differences $(P=.01)$ observed among the cultivars in $\mathrm{J}_{2}$ count per $10 \mathrm{~g}$ of roots (Table 1 ) in both growing seasons. In both growing seasons, Kwachanjiwa had the lowest $\mathrm{J}_{2}$ count per $10 \mathrm{~g}$ of roots (Table 1 ). Kwatolotolo had the highest $\mathrm{J}_{2}$ count per $10 \mathrm{~g}$ of roots in both 2002 and 2003 with mean values of 11 in each season.

In both $\mathrm{J}_{2}$ count per $10 \mathrm{~g}$ of roots and in $\mathrm{J}_{2}$ count in $250 \mathrm{~cm}^{-3}$ of soil at maturity, Kwachanjiwa had the lowest mean values of 11 and 797, respectively, while the highest values were obtained from Kwatolotolo (Table 2).

\subsection{Effects of Carbofuran Application on the Performance of} Bambara Groundnut. There was no significant difference $(P=.05)$ in plant height, flower count, and nodulation count between cultivars in 2002 and 2003 growing seasons (Table 3) as well as the pooled data over the 2 growing seasons (Table 2). Similarly, no significant differences $(P=$ $.05)$ were observed in nodulation count between the cultivars in both growing seasons (Table 3 ). However, the pooled data over the 2 growing seasons showed that there were significant differences $(P=.05)$ in nodulation count between the cultivars (Table 2). The lowest number of nodules was observed from the cultivar Kwaheuma with a mean value of 30 nodules while the highest mean number of nodules was recorded from the cultivar Kwatolotolo which had a mean value of 41 nodules.

In 2002 and 2003 growing seasons, galling index was the lowest when carbofuran was applied at planting with mean values of 1.22 and 0.78 , respectively (Table 3 ). The control treatment had the highest galling index in both seasons with mean values of 4.11 and 3.94 for 2002 and 2003 seasons, respectively. Analysis of the pooled data over two seasons showed that the galling index from plots that received carbofuran at planting was 1.0 which was the lowest, while the control plots had galling index of 4.03. On the other hand, no significant differences $(P=.05)$ were observed in galling index between cultivars in 2002 and 2003 growing seasons (Table 3 ). However, the pooled data over the 2 growing seasons showed that there were significant differences $(P=.05)$ in galling indices between the cultivars (Table 2). The cultivar Kwatolotolo had the lowest galling index of 2.33 while the highest value was from the cultivar Kwaheuma which had a mean value of 2.69.

There were significant differences $(P=.01)$ in grain yield between the time of application of carbofuran (Table 3 ). The highest grain yields of 726 and $788 \mathrm{~kg} \mathrm{ha}^{-1}$ were obtained from carbofuran at planting in 2002 and 2003, respectively. Similar trends were observed for the pooled data over the 2 growing seasons (Table 2 ).

There were significant differences $(P=.01)$ between the cultivars in grain yields in 2002 growing season only (Table 3). The cultivar Kwatolotolo had the highest grain yield of $479.46 \mathrm{~kg} \mathrm{ha}^{-1}$ in 2002 season. No significant difference $(P=.05)$ was between Kwatolotolo and Kwachanjiwa in grain yields. The cultivar Kwaheuma consistently had the lowest grain yield.

Significant differences $(P=.01)$ were observed in grain yield among the cultivars from the analysis of the pooled data over the 2 growing seasons (Table 2 ). The highest grain yield of $471 \mathrm{~kg} \mathrm{ha}^{-1}$ was obtained from Kwatolotolo.

There was no significant interaction $(P=.05)$ between growing season and cultivar in all the parameters taken except plant height at 10 WAS where significant interaction was observed between growing season and cultivar $(P=.05)$. Similarly, there was no significant interaction $(P=.05)$ between cultivar and time of carbofuran application in all the parameters taken except $\mathrm{J}_{2}$ count per $10 \mathrm{~g}$ of roots and grain 
TABle 2: Pooled means of the effects of application of carbofuran to control M. javanica on the characteristics of $M$. javanica and the performance of bambara groundnut in 2002 and 2003 cropping seasons.

\begin{tabular}{|c|c|c|c|c|c|c|c|c|}
\hline Treatment & $\begin{array}{c}\mathrm{J}_{2} / 250 \mathrm{~cm}^{3} \\
\text { soil at } \\
\text { planting }\end{array}$ & $\begin{array}{l}\mathrm{J}_{2} / 10 \mathrm{~g} \\
\text { of roots }\end{array}$ & $\begin{array}{c}\mathrm{J}_{2} / 250 \mathrm{~cm}^{3} \\
\text { soil at } \\
\text { maturity }\end{array}$ & $\begin{array}{l}\text { Plant } \\
\text { height }\end{array}$ & $\begin{array}{c}\text { Flower } \\
\text { count }\end{array}$ & $\begin{array}{c}\text { No of } \\
\text { nodules }\end{array}$ & $\begin{array}{l}\text { Galling } \\
\text { index }\end{array}$ & $\begin{array}{c}\text { Grain } \\
\text { yield }\end{array}$ \\
\hline \multicolumn{9}{|c|}{ Application time } \\
\hline Control & 1067.8 & 33.00 & 2030.9 & 25.37 & 12.50 & 35.89 & 4.03 & 200.14 \\
\hline At planting & 1051.4 & 5.44 & 203.2 & 28.86 & 11.78 & 36.78 & 1.00 & 756.73 \\
\hline 3 WAS & 989.4 & 16.44 & 760.9 & 27.2 & 11.67 & 33.11 & 2.36 & 361.88 \\
\hline 6WAS & 892.7 & 20.22 & 1095.1 & 26.2 & 11.88 & 39.44 & 2.86 & 377.46 \\
\hline Prob. of F & ns & ns & * & ns & $* *$ & * & * & $* *$ \\
\hline S.E. & 147.36 & 4.07 & 136.41 & 0.49 & 0.82 & 3.54 & 0.19 & 28.41 \\
\hline \multicolumn{9}{|l|}{ Cultivars } \\
\hline Kwachanjiwa & 1071.7 & 10.92 & 796.9 & 26.55 & 11.25 & 38.33 & 2.67 & 459.81 \\
\hline Kwaheuma & 933.8 & 14.92 & 1042.6 & 27.44 & 11.88 & 29.88 & 2.69 & 341.81 \\
\hline Kwatolotolo & 994.9 & 30.50 & 1228.2 & 27.53 & 12.75 & 40.71 & 2.33 & 470.69 \\
\hline Prob. of F & $* *$ & ns & $* *$ & ns & $* *$ & $* *$ & $* *$ & $* *$ \\
\hline S.E. & 143.15 & 4.57 & 157.57 & 0.57 & 0.95 & 4.09 & 0.22 & 49.18 \\
\hline $\mathrm{TP} \times$ Cultivar & ns & ns & ns & ns & ns & ns & ns & ns \\
\hline
\end{tabular}

TP: time of application, ${ }^{*}$ significantly different at $P=.05,{ }^{*} *$ significantly different at $P=.01$, ns: non-significantly different at $P=.05$.

TABLE 3: Effects of application of carbofuran to control M. javanica on the performance of bambara groundnut taken in 2002 and 2003 cropping seasons.

\begin{tabular}{lcccccccccc}
\hline Treatment & \multicolumn{2}{c}{ Plant height } & \multicolumn{2}{c}{ Flower count } & \multicolumn{2}{c}{ Nodulation } & \multicolumn{2}{c}{ Galling index } & \multicolumn{2}{c}{ Grain yield } \\
Application time & 2002 & 2003 & 2002 & 2003 & 2002 & 2003 & 2002 & 2003 & 2002 & 2003 \\
\hline Control & 26.67 & 24.08 & 10.33 & 14.67 & 35.22 & 36.56 & 4.11 & 3.94 & 229.30 & 170.99 \\
At planting & 27.70 & 30.01 & 9.11 & 14.44 & 36.22 & 37.33 & 1.22 & 0.78 & 725.50 & 787.97 \\
3WAS & 28.76 & 27.11 & 9.33 & 14.00 & 32.33 & 33.39 & 2.28 & 2.44 & 372.12 & 351.3 \\
6WAS & 26.54 & 26.50 & 9.56 & 14.22 & 39.56 & 39.33 & 3.00 & 2.72 & 373.51 & 381.41 \\
Prob. of F & $*$ & $* *$ & $\mathrm{~ns}$ & $\mathrm{~ns}$ & $\mathrm{~ns}$ & $\mathrm{~ns}$ & $* *$ & $* *$ & $* *$ & $* *$ \\
S.E. & 0.75 & 0.65 & 0.49 & 1.57 & 5.52 & 4.8 & 0.26 & 0.29 & 70.65 & 47.62 \\
Cultivars & & & & & & & & & \\
Kwachanjiwa & 26.19 & 26.90 & 9.00 & 13.50 & 37.50 & 39.17 & 2.83 & 2.50 & 452.72 & 466.90 \\
Kwaheuma & 27.99 & 26.88 & 9.92 & 13.83 & 28.42 & 31.33 & 2.75 & 2.63 & 343.16 & 340.23 \\
Kwatolotolo & 28.07 & 26.99 & 9.83 & 16.67 & 41.8 & 39.83 & 2.38 & 2.29 & 479.46 & 461.23 \\
Prob. of F & $\mathrm{ns}$ & $\mathrm{ns}$ & $\mathrm{ns}$ & $\mathrm{ns}$ & $\mathrm{ns}$ & $\mathrm{ns}$ & $\mathrm{ns}$ & $\mathrm{ns}$ & $* *$ \\
S.E. & 0.59 & 0.75 & 0.56 & 1.82 & 6.20 & 5.29 & 0.29 & 0.34 & 81.67 & 55.05 \\
TP $\times$ Cultivar & $\mathrm{ns}$ & $*$ & $\mathrm{~ns}$ & $\mathrm{~ns}$ & $\mathrm{~ns}$ & $\mathrm{~ns}$ & $\mathrm{~ns}$ & $\mathrm{~ns}$ & $\mathrm{~ns}$ \\
\hline
\end{tabular}

TP: time of application, ${ }^{*}$ significantly different at $P=.05,{ }^{* *}$ significantly different at $P=.01$, ns: non-significantly different at $P=.05$.

yield where significant interactions were observed between cultivar and time of carbofuran application $(P=.01)$.

\section{Discussion}

The result of this work shows that while nematodes affect plant growth, the application of carbofuran improved the growth of bambara groundnut depending on the time of application and the variety. This agrees with the findings of other workers who recorded increased growth parameters with application of carbofuran [5-8]. The applications of carbofuran in this work were effective in controlling root knot nematodes (M. javanica), with application at the time of planting being the most effective. Better performance from Kwachanjiwa in the growth parameters measured and grain yield indicates that the chemical is more effective on the cultivar. The low flower count observed in plots that received carbofuran application when compared to that of the control suggests the phytotoxicity effect of the chemical. It was earlier on reported that carbofuran has some phytotoxicity effect on the roots of tomato [10].

The significant differences observed in the time of carbofuran application in grain yield of bambara groundnuts might indicate that this time of application is important in reducing nematode population and the resultant effects of the nematodes on the grain yield of the crop. Application 
at planting might reduce the population of nematodes early enough and ensure that nematodes present in the soil that may reduce growth and yield will be fewer in number. If the application is delayed, there may be more nematodes in the soil at an early stage, which will affect early growth and subsequent performance of the crop. The success of carbofuran in controlling $M$. javanica and increasing the yield of bambara groundnut could be attributed to sandy loam nature of the soil. It has been established that carbofuran is most effective in sandy soil, when applied to control Globodera rostochiensis on potato [11]. Kwachanjiwa and Kwatolotolo appear to respond more to the carbofuran application which resulted in higher grain yields. It might also indicate better tolerant nature of the two cultivars to $M$. javanica.

\section{Conclusion}

Although carbofuran rate applied did not completely eliminate nematodes, it was effective in controlling $M$. javanica on bambara groundnut. The use of carbofuran at planting was the most effective application timing to reduce $M$. javanica population levels. Meloidogyne javanica nematode counts were reduced in soil treated with carbofuran which lead to improved plant growth and yield. The bambara groundnut cultivars, Kwachanjiwa and Kwatolotolo, also provided higher yields and lower $M$. javanica population levels compared to Kwaheuma. This study indicated that carbofuran can be applied at $4 \mathrm{~kg} / \mathrm{ha}$ to control M. javanica, with the cultivars Kwachanjiwa and Kwatolotolo providing the best results.

\section{References}

[1] J. R. J. Rowland, Dryland Farming in Africa, Macmillan, London, UK, 1994.

[2] B. Tanimu, "Effect of sowing dates and inter-row spacing on the yield and yield characteristics of Two Bambara groundnut varieties," African Crop Sciences Proceeding, vol. 3, pp. 779-785, 1997.

[3] C. P. Disanzo, "Nematode response to carbofuran," Journal of Nematology, vol. 5, pp. 22-27, 1975.

[4] V. A. Ajayi, C. M. Akem, and S. O. Adesiyan, "Comparison of nematicidal comparison of nematicidal potential of Venonia amygdalina leaf extract and carbofaran on the growth and yield of root-knot nematode infested soybean," Afro-Asian Journal of Nematology, vol. 3, no. 2, pp. 119-127, 1993.

[5] A. A. Adegbite and G. O. Agbaje, "Efficacy of carbofuran in control of root-knot nematode (Meloidogyne incognita race 2) in hybrid yam varieties in southwestern Nigeria," Electronic Journal of Environmental, Agricultural and Food Chemistry, vol. 6, no. 6, pp. 2083-2094, 2007.

[6] E. A. Akinlade and S. O. Adesiyan, "The efficacy of Carbofuran in controlling Meloidogyne incognita on Okra (Abelmoschus esculentus)," Nigerian Journal of Pesticides and Agricultural Chemical, vol. 1, pp. 22-27, 1982.

[7] A. A. Adegbite and S. O. Adesiyan, "Effect of Carbofuran (Furadan) on the performance of four Nematode susceptible varieties of soybean (Glycine max (L.) Merr," Tropical Oilseeds Journal, vol. 6, pp. 11-23, 2001.
[8] O. K. Adekunle and B. Fawole, "Chemical and non chemical control of Meloidogyne incognita infecting cowpea under field conditions," Moor Journal of Agricultural Research, vol. 4, no. 1, pp. 94-99, 2003.

[9] K. R. Barker, "Nematode extraction and bioassay," in An Advanced Treatise on Meloidogyne Volume II Methodology, K. R. Barker, C. C. Carter, and J. N. Sasser, Eds., pp. 19-35, North Carolina State University Graphics, 1985.

[10] P. Crozzoli and R. G. Diego, "Control of the root-knot nematode, Meloidogyne incognita (Kofoid and White, 1919) Chitco 1994," in Tomatoes Treated with Cincocin and Carbofuran, 1991, http://www.agrisciences.com/pdf/DATA/R214.pdf.

[11] M. Da-Tadzadeh and M. G. N. Hague, "The efficacy of carbofuran against the potato cyst nematode, Globodera rostochiensis," Revue Nematology, vol. 4, no. 1, pp. 121-124, 1981. 


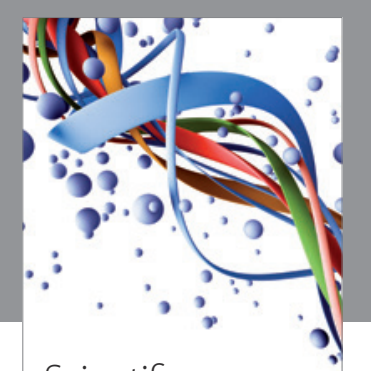

Scientifica
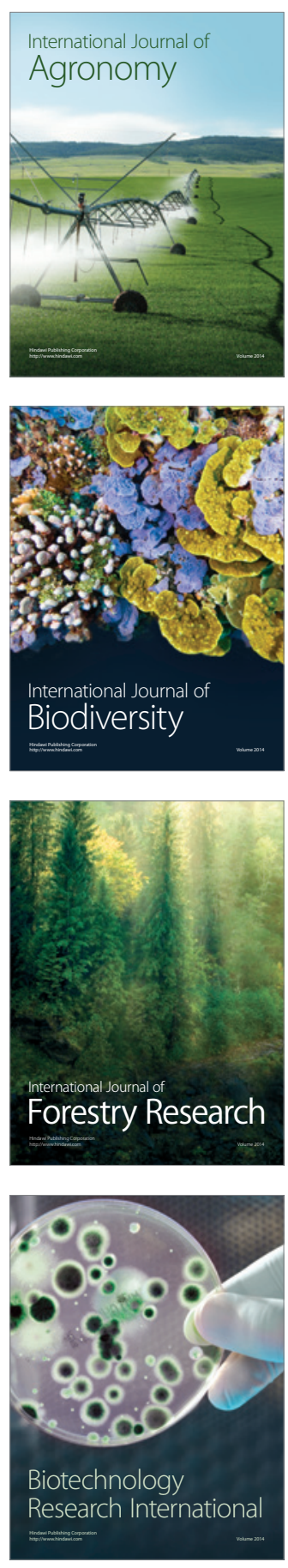
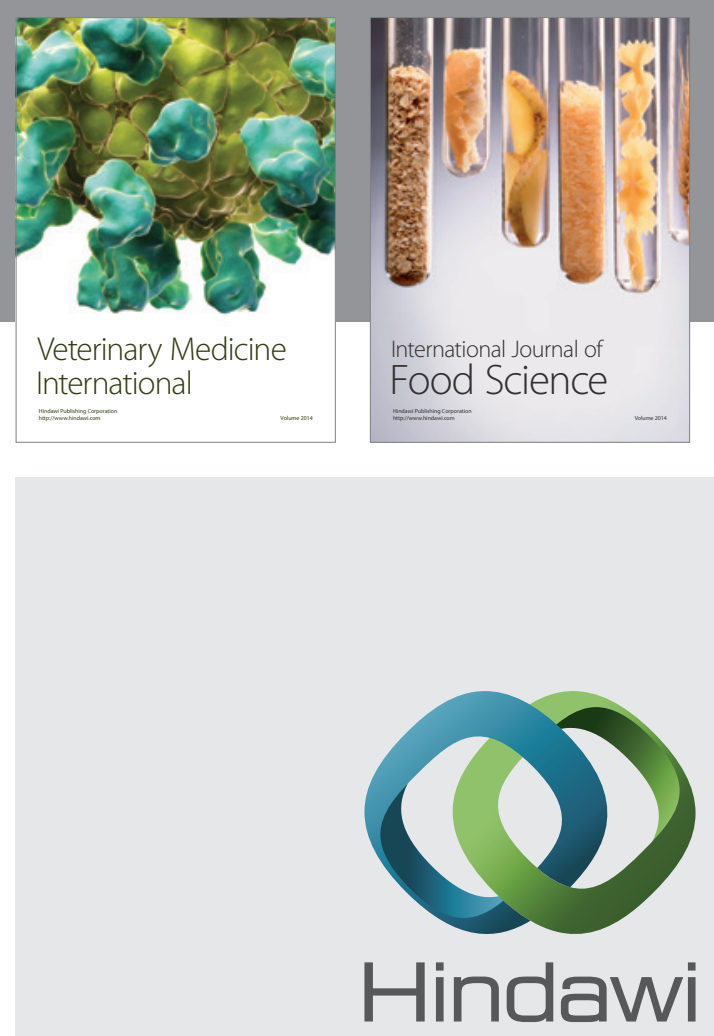

Submit your manuscripts at

http://www.hindawi.com
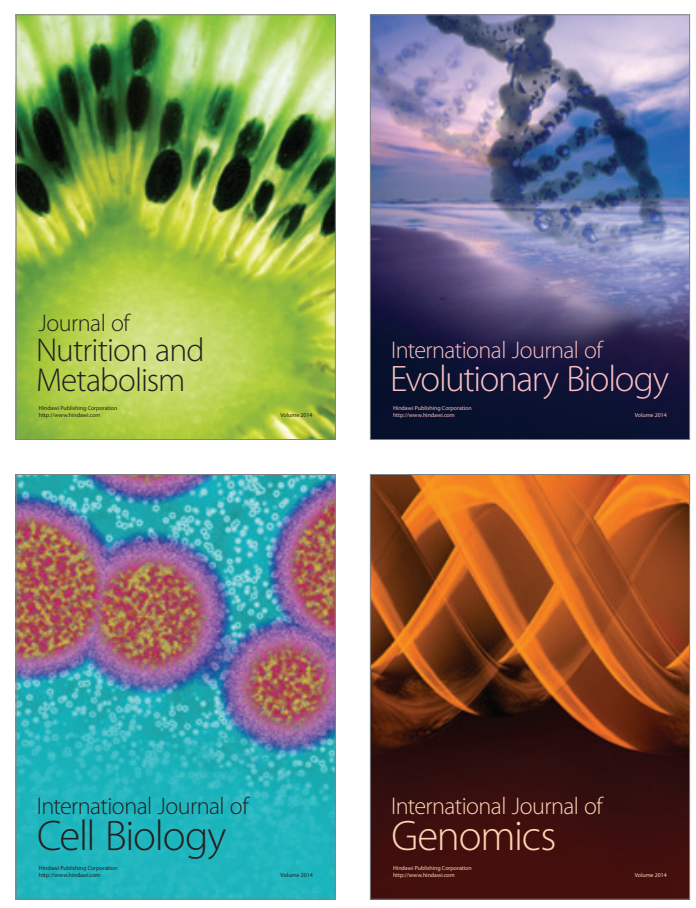
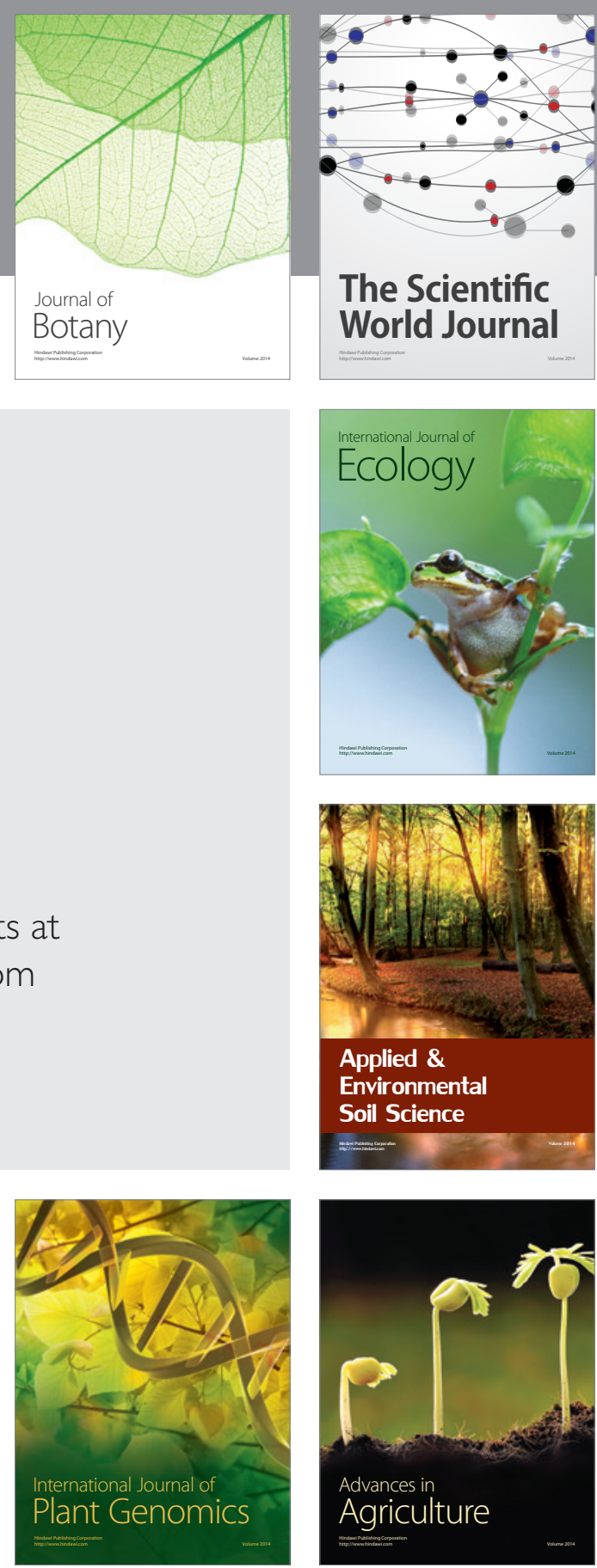

The Scientific World Journal
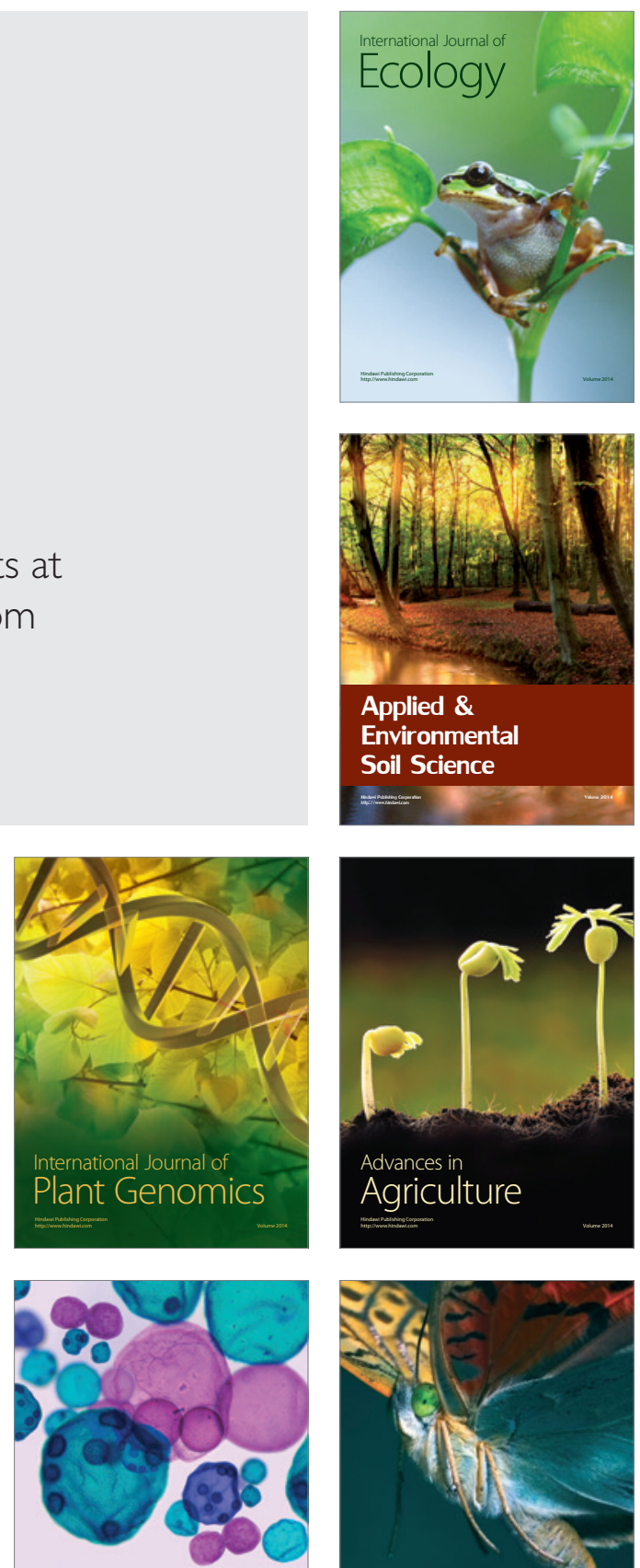

International Journal of Microbiology

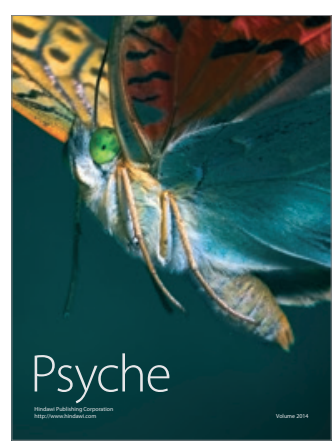

